\title{
Impact of Bio fertilizers on Growth and Yield Attributes of Onion (Allium cepa L.) var. AFLR
}

\author{
Nency Verma, R. K. Jaiswal, S. A. Ali and Raj Kumar Dhakad*
}

Department of Horticulture, Vegetable Science, Rajmata Vijayaraje Scindia Krishi Vishwa Vidhyalaya, Gwalior, R.A.K College of Agriculture, Sehore, M.P. India

*Corresponding author

\section{A B S T R A C T}

\section{Keywords}

Plant height, Number of leaves, Leaf width, Bolting percentage and Bulb yield

\section{Article Info}

Accepted: 10 January 2021 Available Online: 10 February 2021
The experiment was carried out at the Horticulture Research Farm, R.A.K college of Agriculture, Sehore (M.P.), India during rabi 2019-2020 and the experiment was laid out in the randomized block design with ten treatments. Among various treatments of onion, it was observed that the plant height was significantly increased in various growth stage (30, 45, 60 and 90 DAT). Plant height of treatment $\mathrm{T}_{8}(\mathrm{Vc}+$ Azospirillum $(1 / 3$ dose $)+$ VAM (1/3dose) + PSB (1/3 dose) was found significantly superior at 30 DAT $(29.27 \mathrm{~cm}), 45$ DAT $(38.37 \mathrm{~cm}), 60$ DAT $(45.63 \mathrm{~cm})$ and 90 DAT $(66.80 \mathrm{~cm})$ while Treatment $\mathrm{T}_{1}$ (control) performed poorly. Regarding the number of leaves per plant in various growth stages treatment $\mathrm{T}_{8}$ again found significantly superior due to heavy vegetative growth as compared to $\mathrm{T}_{9} \mathrm{~T}_{10}$ and $\mathrm{T}_{7}$. However, lowest number of leaves per plant found were noticed in $\mathrm{T}_{1}$ (control) and the minimum number of bolted plant per plot and bolting percentage was found in $\mathrm{T}_{8}$ and in relation to yield parameters satisfactory maximum bulb yield per plot and per hectare yield $\mathrm{q} /$ ha was recorded again in treatment $\mathrm{T}_{8}$ (11.40) and (301.58) respectively in this experiment overall treatment $t 8$ is found superior in all stages

\section{Introduction}

Onion (Allium cepa L.) is one of the most important and famous commercial vegetable crop grown all over the world also in India. It belongs to family Amaryllidaceae and commonly known as "pyaj" in Hindi. The crop is native of Asia (Jones and Mann, 1963). It is hardy bulbous and winter plant grown as annual for bulb production and biennial for seed production. Now a day's no one dish is completed without onion and it is widely used throughout the year as salad, culinary purpose for flavoring as spices in pickles, sauce and vegetable. It occupies an important position among all the vegetable crops in kitchen garden as well as commercial production and plays a vital role in Indian economy.

Onion is an immense potential crop being part of medicinal value and hence, useful in fever, dropsy and chronic bronchitis. it is consumed as a vegetable and condiment. The green leaves, immature and matured bulbs are eaten raw or used in vegetable preparations. 
The pungency of onion is due to presence of Sulphur compound in very small quantity (about $0.005 \%$ ) in the volatile oil of the bulb juice. The main compound is allyl propyl disulphide $\left(\mathrm{C}_{6} \mathrm{H}_{12} \mathrm{O}_{2}\right)$. The red colour of onion is due to the presence of pigment anthocyanin and yellow colour is due to quercetin. It affords an excellent form of food iron and on this account many often be eaten freely with advantage by persons suffering from anemia. India is the second largest producer of onion in the world followed by china, while India ranks first in terms of area. The major onion producing states are Maharashtra, Madhya Pradesh, Karnataka, Bihar, Gujarat, etc. India having the total area (1258.0 Thousand ha), production (23262 Thousand MT) and productivity $(18.1 \mathrm{t} / \mathrm{ha})$ of onion in 2018 . In Madhya Pradesh total area of onion is 150.87 Thousand ha with 3701.01 Thousand MT production and 17.50 t/ha productivity (Anonymous, 2018). There is a need to search alternative nutrient source, which could be cheap and eco-friendly so that farmers may be able to reduce the investment made on fertilizer along with maintaining good soil environmental conditions leading to ecological sustainable farming, bio-fertilizers like VAM, Azotobactor, Azospirillum, PSB and organic fertilizers like vermi-compost, NADEP compost, FYM, poultry manure is very popular among the farmers and easily produced.

Usually little or no chemical fertilizer is added to this crop and hence characterized by low yield. Therefore, there is a need to study the possible ways of improving the yields of this crop. Bio-fertilizer has recently gained with momentum for affecting the sustainable increase in crop yield under various agro climatic conditions. Biofertilizers are live carrier based microbial preparations used in agriculture as low input resources to enhance the availability of plant nutrients or promote the growth by way of synthesizing growth factors. Role of bio-fertilizer on the crop growth and yield was documented by (Vijayakumar et al., 2000) and (Ramakrishnan and Thamizhiniyan, 2004).

\section{Materials and Methods}

The experiment was carried out at the Horticulture Research Farm, R.A.K college of Agriculture, Sehore (M.P.) during rabi 20192020. The experimental site is situated in the western part of the Vindhya Plateau at $23.11^{\circ}$ North latitude and $77.04^{\circ}$ ' East longitudes at an altitude of 502 meter above mean sea level in Madhya Pradesh. The experiment was laid out with three replications and ten treatments. The pant to plant and row to row distance were taken 10 X 15sqm respectively

The topography of the experimental field is plain. The region lies under $5^{\text {th }}$ agro-climatic zone of state. Sehore belongs to sub-tropical zone. The summers here have a good deal of rainfall, while the winters have very little. The average temperature is about $25.3^{\circ} \mathrm{C}$. The rainfall here is around $1266 \mathrm{~mm}$ (49.8 inch per year).

The highest temperature recorded in the month of May at around $33.8^{\circ} \mathrm{C}$ whereas January is the coldest month with temperature $18.6^{\circ} \mathrm{C}$. Temperatures in the summer range from 25 to $45{ }^{\circ} \mathrm{C}$, while the temperature in winter is 10 to $25^{\circ} \mathrm{C}$. Meteorological data recorded during the period of investigation. Before laying out the experiment, random soil samples were collected from the different spots of the experimental field at $0-15 \mathrm{~cm}$ depth and the composite sample was prepared which was analyzed for various chemical properties of the soil. The soil of experimental field was medium black with good drainage facilities and uniform texture with low $\mathrm{N}$ and medium $\mathrm{P}_{2} \mathrm{O}_{5}, \mathrm{~K}_{2} \mathrm{O}$ status.

The following treatments were taken during experiment (Table 1). All the plant nutrients were applied through bio-fertilizers like 
Azospirillum (@2kg/ha),VAM (@2kg/ha) and PSB (@ 2kg/ha) According to treatments. These all bio-fertilizers were applied with vermicompost (@5t/ha) after 20 days of transplanting.

All the intercultural operations like weeding watering, gap filling etc were carried out during the research experiment.

\section{Results and Discussion}

The above investigation entitled "Evaluation of bio fertilizers on growth and yield attributes of onion (Allium cepa L.) Var. AFLR." Was conducted at experimental field of Horticulture R. A. K., College of Agriculture, Sehore (MP). The result obtained from this investigation, according to different parameter has been presented and explained blow.

\section{Growth parameters}

The growth parameters like plant height, number of leaf and leaf length was recorded at 30, 45, 60 and 90 days after transplanting and it is shown in table 2 and fig. 1.

\section{Plant height}

The highest plant height were recorded with treatment $\mathrm{T} 8$ at deferent growth stage that is at 30 DAT $(29.27 \mathrm{~cm}), 45$ DAT $(38.37 \mathrm{~cm}), 60$ DAT $(45.63 \mathrm{~cm})$ and 90 DAT $(66.80 \mathrm{~cm})$ while there were no significant differences between the control. It might be due to the positive effect of treatment T8 $(\mathrm{Vc}+$ Azospirillum $(1 / 3$ dose $)+\operatorname{VAM}(1 / 3$ dose $)+\operatorname{PSB}(1 / 3$ dose $)$ and positive combination of above treatment.

This treatment provide good amount of nutrients and fertilizer for their growth. Probable increase in plant height may be due to increased soil nutrient uptake and effective translocation to various plant parts by the effect of biofertilizers. The result of this investigation concerning maximum plant height are consistent with the findings previously reported in onion by Desale (1980), Dibut et al., (1993), Wange (1998), Bhonde (1997), Dharmendra et al., (2001), Alkaff et al., (2002), Jayanthilake et al., (2002), Singh et al., (2002), Rather et al., (2003), Ruban (2007), Sankar et al., (2009b).

\section{Number of leaves}

The maximum number of leaves per plant was significantly recorded in treatment $\mathrm{T}_{8}$ at 30 DAT (4.33) 45 DAT (5.67), 60 DAT (8.33) and 90 DAT (11.00). The treatment T8 was performed best out of other treatments it might be due to highest accumulation of photosynthetes or positive correlation between treatment $\mathrm{T} 8$ compositions. The poor performance is recorded with the treatment T1 it might be due to the poor accumulation of photosynthetes or poor absorption of nutrient it might. These findings are also consonance by Desale (1980), Gupta et al., (1998), Dibut et al., (1993), Sankar, et al., (2009b).

\section{Leaf length}

The increasing nature of length of leaf of the plant is recorded at 30, 45, 60 and 90 days after transplanting and the maximum leaf length per plant was significantly recorded in treatment $\mathrm{T}_{8}$ at 30 DAT $(25.00 \mathrm{~cm}) 45$ DAT $(29.40 \mathrm{~cm}), 60$ DAT $(37.43 \mathrm{~cm})$ and 90 DAT $(50.90 \mathrm{~cm})$.

\section{Yield parameters}

\section{Weight of bulb}

Fresh weight of the bulb, dry weight of bulb, Number of bolting, bolting percentage and bulb yield were calculated during the experimental research in the yield parameters 
as shown in table 3 and fig. 2. After harvesting of bulbs the fresh weight was significantly maximum recorded in treatment $\mathrm{T}_{8}$ (147.67) and at par $\mathrm{T}_{9}$ (144.67), followed by $_{10}$ (143.00), $\mathrm{T}_{5}$ (139.33), $\mathrm{T}_{7}(137.33), \mathrm{T}_{6}$ (136.67), $\mathrm{T}_{2}$ (134.00), $\mathrm{T}_{3}(131.00), \mathrm{T}_{4}$ (129.33) while the minimum leaf area index is reported in $T_{1}$ (127.67). From the analysis of study, the fresh weight is varies due to different level of treatments These finding related to result Musmade et al., (1980), Bhonde et al., (1997), Nagaraju et al., (2000), Sharma et al., (2003), Sankar et al., (2009b), Singh et al., (2015),

Table. 1 Treatment details

\begin{tabular}{|c|l|}
\hline Treatment & \multicolumn{1}{|c|}{ Doses } \\
\hline $\mathbf{T}_{\mathbf{1}}$ & Control \\
\hline $\mathbf{T}_{\mathbf{2}}$ & Vermicompost $(\mathrm{Vc})+$ Azospirillumfull dose $(5 \mathrm{t} / \mathrm{ha}+2 \mathrm{~kg} / \mathrm{ha})$ \\
\hline $\mathbf{T}_{\mathbf{3}}$ & Vc+VAM full dose $(5 \mathrm{t} / \mathrm{ha}+2 \mathrm{~kg} / \mathrm{ha})$ \\
\hline $\mathbf{T}_{\mathbf{4}}$ & Vc+ PSB full dose $(5 \mathrm{t} / \mathrm{ha}+2.5 \mathrm{~kg} / \mathrm{ha})$ \\
\hline $\mathbf{T}_{\mathbf{5}}$ & Vc+Azospirillum full dose $+\mathrm{VAM}(1 / 2 \mathrm{dose}) 5 \mathrm{t} / \mathrm{ha}+2 \mathrm{~kg} / \mathrm{ha}+1 \mathrm{~kg} / \mathrm{ha})$ \\
\hline $\mathbf{T}_{\mathbf{6}}$ & Vc+Azospirillum full dose+ PSB $(1 / 2$ dose $)(5 \mathrm{t} / \mathrm{ha}+2 \mathrm{~kg} / \mathrm{ha}+1.25 \mathrm{~kg} / \mathrm{ha})$ \\
\hline $\mathbf{T}_{\mathbf{7}}$ & Vc + VAM full dose + Azospirillum $(1 / 2 \mathrm{dose})(5 \mathrm{t} / \mathrm{ha}+2 \mathrm{~kg} / \mathrm{ha}+1 \mathrm{~kg} / \mathrm{ha})$ \\
\hline $\mathbf{T}_{\mathbf{8}}$ & Vc+Azospirillum+VAM+PSB $(1 / 3$ dose $)(5 \mathrm{t} / \mathrm{ha}+666 \mathrm{~g} / \mathrm{ha}+666 \mathrm{~g} / \mathrm{ha}+833 \mathrm{~g} / \mathrm{ha})$ \\
\hline $\mathbf{T}_{\mathbf{9}}$ & Vc+Azospirillum+VAM+PSB $(1 / 2$ dose $)(5 \mathrm{t} / \mathrm{ha}+1 \mathrm{~kg} / \mathrm{ha}+1 \mathrm{~kg} / \mathrm{ha}+1.25 \mathrm{~kg} / \mathrm{ha})$ \\
\hline $\mathbf{T}_{\mathbf{1 0}}$ & Vc+Azospirillum+VAM+PSB(full dose $)(5 \mathrm{t} / \mathrm{ha}+2 \mathrm{~kg} / \mathrm{ha}+2 \mathrm{~kg} / \mathrm{ha}+2.5 \mathrm{~kg} / \mathrm{ha})$ \\
\hline
\end{tabular}

Table.2 Impact of bio fertilizer on growth and growth attributes at deferent stages of crops experiment

\begin{tabular}{|c|c|c|c|c|c|c|c|c|c|c|c|c|}
\hline \multirow[t]{2}{*}{ Treatments } & \multicolumn{4}{|c|}{ Plant height (cm) } & \multicolumn{4}{|c|}{ Number of leaves } & \multicolumn{4}{|c|}{ Leaf length (cm) } \\
\hline & $\begin{array}{l}\text { 30 } \\
\text { DAT }\end{array}$ & $\begin{array}{l}45 \\
\text { DAT }\end{array}$ & $\begin{array}{l}60 \\
\text { DAT }\end{array}$ & 90 DAT & $\begin{array}{l}\text { 30 } \\
\text { DAT }\end{array}$ & $\begin{array}{l}45 \\
\text { DAT }\end{array}$ & $\begin{array}{l}\text { 60 } \\
\text { DAT }\end{array}$ & $\begin{array}{l}90 \\
\text { DAT }\end{array}$ & $\begin{array}{l}\text { 30 } \\
\text { DAT }\end{array}$ & $\begin{array}{l}45 \\
\text { DAT }\end{array}$ & $\begin{array}{l}60 \\
\text { DAT }\end{array}$ & $\begin{array}{l}90 \\
\text { DAT }\end{array}$ \\
\hline $\mathbf{T}_{1}$ & 25.13 & 34.40 & 41.83 & 62.00 & 3.00 & 4.00 & 6.00 & 8.00 & 21.63 & 25.90 & 30.70 & 45.53 \\
\hline $\mathbf{T}_{2}$ & 25.80 & 35.60 & 42.50 & 62.87 & 3.33 & 4.33 & 6.33 & 8.33 & 21.97 & 26.50 & 34.20 & 47.07 \\
\hline $\mathbf{T}_{3}$ & 25.70 & 37.90 & 42.40 & 62.83 & 3.33 & 4.33 & 6.33 & 8.33 & 22.43 & 26.63 & 34.07 & 48.67 \\
\hline $\mathbf{T}_{4}$ & 26.10 & 37.70 & 42.80 & 64.67 & 3.33 & 4.00 & 6.33 & 8.67 & 22.00 & 26.00 & 34.30 & 47.80 \\
\hline $\mathbf{T}_{5}$ & 26.97 & 37.53 & 43.67 & 65.10 & 4.00 & 4.67 & 6.67 & 9.67 & 22.73 & 27.17 & 34.97 & 46.97 \\
\hline$T_{6}$ & 28.97 & 37.70 & 44.93 & 66.27 & 3.33 & 4.33 & 6.33 & 9.33 & 23.30 & 27.87 & 34.80 & 48.40 \\
\hline $\mathbf{T}_{7}$ & 27.27 & 37.87 & 43.63 & 65.47 & 3.33 & 4.67 & 6.67 & 9.67 & 22.43 & 28.27 & 34.30 & 47.40 \\
\hline $\mathbf{T}_{8}$ & 29.27 & 38.37 & 45.63 & 66.80 & 4.33 & 5.67 & 8.33 & 11.0 & 25.00 & 29.40 & 37.43 & 50.90 \\
\hline $\mathbf{T}_{9}$ & 28.43 & 36.93 & 45.43 & 65.83 & 4.00 & 5.33 & 7.33 & 10.33 & 23.97 & 28.53 & 35.73 & 49.50 \\
\hline $\mathbf{T}_{10}$ & 27.50 & 37.20 & 44.20 & 65.47 & 3.67 & 5.33 & 7.00 & 10.00 & 23.03 & 28.23 & 36.50 & 50.33 \\
\hline S.Em \pm & 0.98 & 0.82 & 0.89 & 1.91 & 0.29 & 0.35 & 0.40 & 0.45 & 0.70 & 0.80 & 1.06 & 1.13 \\
\hline C.D. $(5 \%)$ & 2.91 & 2.44 & 2.65 & 5.68 & 0.85 & 1.03 & 1.18 & 1.34 & 2.09 & 2.39 & 3.15 & 3.35 \\
\hline
\end{tabular}


Table.3 Impact of bio fertilizer on yield and yield attributes at deferent stages of crops experiment

\begin{tabular}{|c|c|c|c|c|c|c|c|}
\hline \multirow[t]{2}{*}{ Sr. No. } & \multirow{2}{*}{$\begin{array}{c}\text { Fresh } \\
\text { weight } \\
\text { (g) }\end{array}$} & \multirow{2}{*}{$\begin{array}{c}\text { Dry } \\
\text { weight (g) }\end{array}$} & \multirow{2}{*}{$\begin{array}{l}\text { Equatorial } \\
\text { diameter }\end{array}$} & \multirow{2}{*}{$\begin{array}{c}\text { Number } \\
\text { of } \\
\text { bolting }\end{array}$} & \multirow{2}{*}{$\begin{array}{c}\text { Bolting } \\
\text { percentage }\end{array}$} & \multicolumn{2}{|c|}{ Bulb yield } \\
\hline & & & & & & Kg/plot & q/ha \\
\hline T1 & 127.67 & 16.67 & 4.17 & 2.00 & 1.04 & 9.67 & 255.73 \\
\hline $\mathbf{T} 2$ & 134.67 & 18.33 & 4.27 & 1.00 & 0.52 & 9.77 & 258.37 \\
\hline T3 & 131.00 & 17.00 & 4.20 & 2.00 & 1.04 & 9.87 & 261.02 \\
\hline T4 & 129.33 & 17.67 & 4.63 & 1.00 & 0.52 & 9.83 & 260.14 \\
\hline T5 & 139.33 & 24.33 & 5.17 & 2.00 & 1.04 & 10.37 & 274.24 \\
\hline T6 & 136.67 & 25.33 & 4.93 & 1.00 & 0.52 & 10.40 & 275.13 \\
\hline T7 & 137.33 & 24.33 & 5.03 & 1.00 & 0.52 & 10.77 & 284.83 \\
\hline T8 & 147.67 & 27.67 & 5.53 & 0.67 & 0.35 & 11.40 & 301.58 \\
\hline T9 & 144.67 & 26.67 & 5.07 & 1.00 & 0.52 & 11.37 & 300.70 \\
\hline T10 & 143.00 & 26.00 & 4.90 & 1.67 & 0.87 & 10.57 & 279.54 \\
\hline S. Em \pm & 4.05 & 1.04 & 0.21 & 0.14 & 0.07 & 0.31 & 8.27 \\
\hline C.D. $(5 \%)$ & 12.03 & 3.09 & 0.62 & 0.42 & 0.22 & 0.93 & 24.55 \\
\hline
\end{tabular}

Fig.1 Impact of bio fertilizer on growth and growth attributes at deferent stages of crops experiment

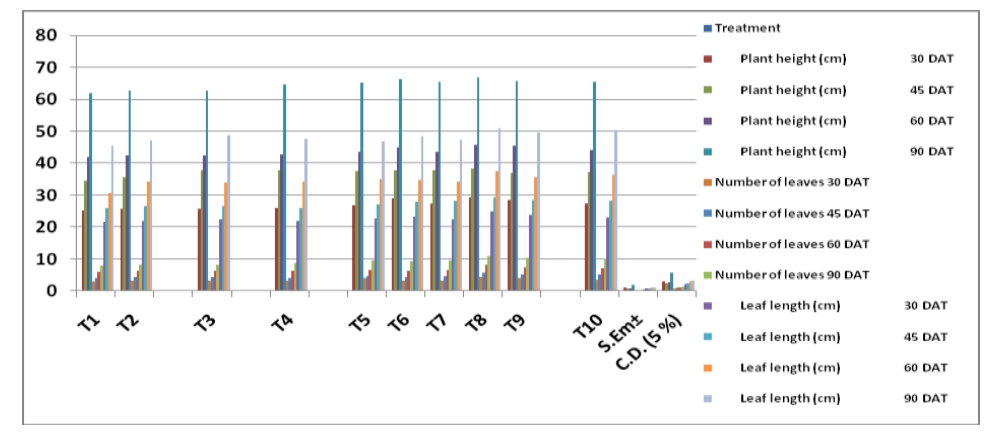

Fig.2 Impact of bio fertilizer on yield and yield attributes at deferent stages of crops experiment

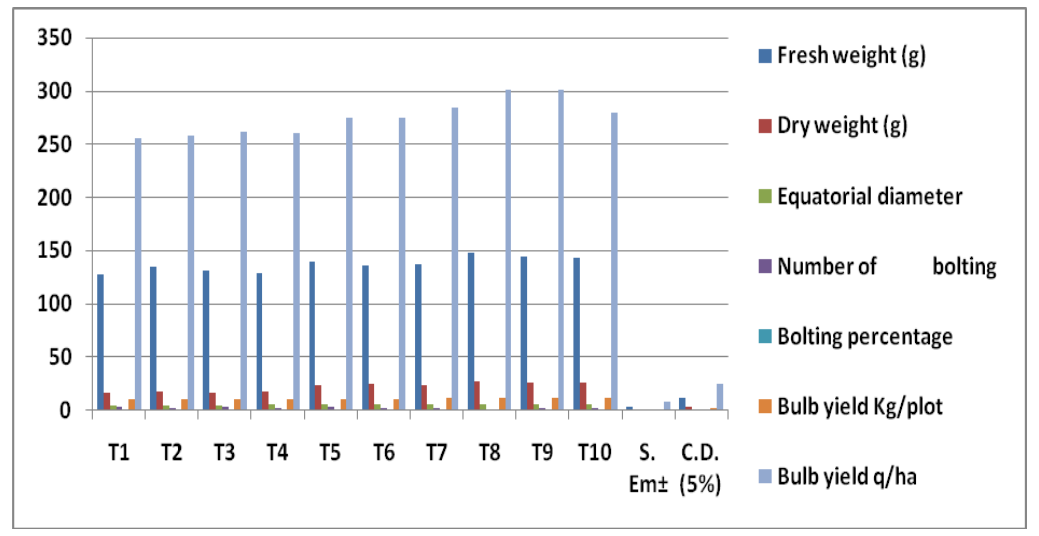


In relation to dry weight, After harvesting of bulbs the dry weight of bulb was significantly maximum recorded in treatment $\mathrm{T}_{8}$ (27.67) and it was at par with the treatment $\mathrm{T}_{9}$ (26.67), followed by $\mathrm{T}_{10}(26.00), \mathrm{T}_{6}(25.33), \mathrm{T}_{5}$ (24.33), $\mathrm{T}_{7}$ (24.33), $\mathrm{T}_{2}$ (18.33), $\mathrm{T}_{4}$ (17.67), $\mathrm{T}_{3}$ (17.00) while the minimum dry weight of bulb is reported in $\mathrm{T}_{1}(16.67)$.

The variation in the fresh weight of bulb and dry weight of bulb might be due to the treatment response. These finding related to result of Desale (1980), Dibut et al., (1993), Martinez et al., (1994), Singh, et al., (2008).

\section{Diameter of bulb}

The equatorial diameter of bulbs was recorded from different treatments. The equatorial diameter of bulbs was significantly maximum recorded in treatment $\mathrm{T}_{8}(5.53)$ and at par $\mathrm{T}_{5}$ (5.17), followed by $\mathrm{T}_{9}$ (5.07), $\mathrm{T}_{7}$ (5.03), T6 (4.93), T10 (4.90), T4 (4.63), $\mathrm{T}_{2}$ (4.27), $\mathrm{T}_{3}$ (4.20) in $\mathrm{T}_{1}$ (4.17) while the minimum equatorial diameter of bulbs was recorded in the treatment $\mathrm{T} 1$. It might be due to the treatment variation. It might also be due to rapid cell division and enlargement which leads to large size of bulb. Similar results were reported by Dibut et al., (1993), Bhonde et al.(1997), Nagaraju et al., (2000), Alkaff et al., (2002), Sharma et al., (2003), Singh et al., (2015), Dilpreet et al., (2016).

\section{Bolting attributes}

While in relation to bolting, the Number of bolted plants per plot was counted before harvesting. The minimum bolted plants were recorded in treatment $\mathrm{T}_{8}(0.67)$ and at par $\mathrm{T}_{2}$ (1.00), $\mathrm{T}_{4}(1.00), \mathrm{T}_{6}(1.00), \mathrm{T}_{7}(1.00), \mathrm{T}_{9}$ (1.00) followed by $_{10}(1.67)$, while the maximum bolted plants recorded in $\mathrm{T}_{3}$ (2.00), $\mathrm{T}_{5}$ (2.00) and $\mathrm{T}_{1}(2.00)$. It might be due to the treatment or soil fertility variation. While the percentage of bolted plant per plot were calculated from the number of bolted plants per plot. Before harvesting of bulbs the percentage of bolted plants were counted, the minimum bolted plant percentage were recorded in treatment $\mathrm{T}_{8}(0.35)$ and it was at par with the treatment $\mathrm{T}_{2}$ (0.52), $\mathrm{T}_{4}$ (0.52), $\mathrm{T}_{6}(0.52), \mathrm{T}_{7}$ (0.52), $\mathrm{T}_{9}$ (0.52) followed by $\mathrm{T}_{10}(0.87)$, while the maximum bolted plants percentage recorded in $\mathrm{T}_{3}$ (1.04), $\mathrm{T}_{5}$ (1.04) and $\mathrm{T}_{1}(1.04)$. Reason for the minimum number of bolting may be due to positive effect of temperature on the onion crop. Similar results were reported by Singh et al., (2008) and Sankar et al., (2009b) in onion.

\section{Yield attributes}

After harvesting, the yield of bulbs were measured in kilograms, the yield of bulbs recorded maximum in treatment $\mathrm{T}_{8}$ (11.40) and at par $\mathrm{T}_{9}$ (11.37), followed by $\mathrm{T}_{7}(10.77)$, $\mathrm{T}_{10}(10.57), \mathrm{T}_{6}(10.40), \mathrm{T}_{5}(10.37), \mathrm{T}_{3}(9.87), \mathrm{T}_{4}$ (9.83), $\mathrm{T}_{2}(9.77)$ while the minimum bulb yield was recorded in $\mathrm{T}_{1}(9.67)$.

After harvesting, the yield of bulbs converted into quintal per hectare, the yield of bulbs recorded maximum in treatment $\mathrm{T}_{8}$ (301.58) and at par $\mathrm{T}_{9}$ (300.70), followed by $\mathrm{T}_{7}$ (284.83), $\quad \mathrm{T}_{10}$ (279.54), $\mathrm{T} 6 \quad$ (275.13), $\mathrm{T} 5$ (274.24), T3 (261.02), T4 (260.14), $\mathrm{T}_{2}$ (258.37) while the minimum bulb yield recorded in $\mathrm{T}_{1}$ (255.73).

The result of this investigation concerning maximum bulb yield per plot and per hectare is consistent with the findings previously reported by Yadav, et al., (2002), Alkaff et al., (2002), Singh, et al.(2008), Sankar et al., (2009b), Singh et al., (2015).

It is concluded that treatment $T_{8}$ is performed best in this research and it is recommended for commercial cultivation of onion in the central India during the kharif season. 


\section{References}

Alkaff, H.A.; Saeed, O.S.; and Salim, A.Z. (2002). Effect of bio-fertilizer, inorganic, organic and foliar application of power 4 on the productivity of onion University of Aden Journal of Natural and Applied Sciences. 6(1): 1-14.

Anonymous (2018). Horticulture Statistic at a Glance, published on Govt. of India, [website-www.agricrop.nic.in] accessed at date $11 / 11 / 19$.

Bhonde, S.R.; Sharma, S.B. and Chougule, A.B. (1997). Effect of biofertilizer in combination with nitrogen through organic and inorganic sources on yield and quality of onion. News Letters, National Hort. Res. Devt. Foundation. 17(2): 1-3.

Desale,A.G. (1980). Effect of bacterization with Azotobacter and Azospirillum cultures under various levels of nitrogen and growth and yield of sorghum and maize. Unpublished M.Sc. (Agri.) thesis submitted to MPKV, Rahuri (M.S.) India.

Dibut, B.; Martinez, R. and Gonzalez, R. (1993). Stimulation of growth and yield of onions by bacterization in red ferrallitic soils. La Habana, Cuba, Instituto Nacional de Investigacioners de la cana de Azucar (INICA). 223-225.

Jones, H.A. and Mann, L.K. (1963). Onion and their Allies. Leonard Hill, (Books) Ltd., London, 1-169.

Martinez, R.; Dibut, B.; Gonzalez, R. and Acosta, C. (1994). Effect of the application of biopreparations based on Azotobacter chroococcumon tomato and onion crops in red ferrallitic soils. 90anos-de-la-Estacion-Experimental-

Agro-nomica-de-Santiago-de-las-

Vegas. Pp. 167-184.

Musmade, B.N. and Konde, B.K. (1980). Effect of inoculation of Azospirillum in yield of onion under field condition.
Curr. Res. Report. 2(2): 72-75.

Nagaraju, R., Haripriya, K., Rajalingam, G.V., Shriramchandrasekaran, V. and Mohindeen, M.K. (2000). Effect of VAM on growth and yield of aggregatum onion (var. Aggregatum don.) South Indian Hort, 48(1/6); 40-45.

Ramakrishnan,K. and Thamizhiniya,P. (2004). The effect of NPK fertilizer and VAM fungi on the yield and quality characters of cotton var. LRA 5166. Plant Arch., 9(1); 87-88.

Sankar, V: Veeraragavathatham, D. and Kannan, M. (2009b). Studies on organic farming in onion (Allium cepa L.) for the production of export quality bulbs. Asian Journal of Horticulture. 4(1): 6569.

Sharma, R.P.; Datta, N. and Sharma, P. (2003). Combined application of nitrogen, phosphorus, potassium and FYM in onion under high hills, dry temperature conditions of NorthWestern Himalayas. Indian J. Agric. Sci., 73 (4): 225-227.

Singh, A.P; Singh, Omvi; Singh, Vinay and Sarvesh Kumar (2008). Effect of integrated use of FYM and inorganic fertilizers on yield and uptake of nutrient by onion. Progressive Agriculture. 8 (2): 256-267.

Singh, A.P; Singh, Omvi; Singh, Vinay and Sarvesh Kumar (2008). Effect of integrated use of FYM and inorganic fertilizers on yield and uptake of nutrient by onion. Progressive Agriculture. 8 (2): 256-267.

Singh, A.; Ram, R.B. and Meena, M.L. (2015). Effect of different sources of nutrients and biofertilizers on growth yield quality of onion. International Research Journal of Natural and Applied Sciences, 2(10) 64-70.

Talwar, Dilpreet, Singh, Kulbir, Sardana, Varinder and Singh, Jagdish (2016). Growth, yield and quality of onion as 
influenced by integrated nutrient management. International Journal of Agriculture Sciences. 8(51): 2295-2298.

Vijayakumar, B.S.; Bhairavamurthy, P.V.; Anand, M.C. (2000). VAM fungi association in Lycopersicon esculentum
L. grown in semi-arid tropical soils of Puttaparthy. A. P. J. Ecobiol., 12(1): 7374.

Yadav, D.S.; Patel, R.K.; Rai, N. and Yadav, R.K. (2002). Progressive Horticulture, (In press).

\section{How to cite this article:}

Nency Verma, R. K. Jaiswal, S. A. Ali and Raj Kumar Dhakad. 2021. Impact of Bio fertilizers on Growth and Yield Attributes of Onion (Allium cepa L.) var. AFLR. Int.J.Curr.Microbiol.App.Sci. 10(02): 931-938. doi: https://doi.org/10.20546/ijcmas.2021.1002.110 